\title{
KONSTITUSIONALITAS STANDAR PELAYANAN MINIMAL
}

\author{
Habib Muhsin Syafingi \\ Fakultas Hukum Universitas Muhammadiyah Magelang \\ Kampus 2 Jl. Mayjen Bambang Sugeng Km 5, Mertoyudan, Magelang \\ +628122774423/basri@ummgl.ac.id
}

\begin{abstract}
The purpose of local government is to realize the people's prosperity through improving services, empowerment, community participation, and enhancement of regional competitiveness. As part of the central government, the local government is responsible for improving public services based on the Minimum Service Standard on the local government obligatory matters that related to the basic needs of the community. The principle of Minimum Service Standard is different from the principle in the Act No. 25 of 2009 about Public Service which tends to emphasize on standard aspects of public goods and public services and more likely focuses toward the realization of good governance. The concern of Minimum Service Standards is the realization of the society's welfare as one of the state goals. The philosophy of this Minimum Service Standard is the improvement of public's quality and access to public services which is should be realized in various indicators. The preparation of indicators along with its achievements and its per year target are intended to evaluate easily and also simplify the planning and budgeting process every year. The obligatory matters of local government related to basic needs should be developed by the ministry concerned and implemented by the local government including education, health, public works and spatial, housing and settlement and social. These government duties based on the result of the study that the Minimum Service Standar on those affairs is the further implementation of the constitutional provisions of the 1945 Constitution, so that the drafting and application of Minimum Service Standar has a clear constitutional foundation.
\end{abstract}

Keyword: Minimum Service Standard; Public Service; Constitution; Constitutionality

\section{Abstrak}

Terwujudnya kesejahteraan masyarakat melalui peningkatan pelayanan, pemberdayaan, peran serta masyarakat, serta peningkatan daya saing daerah merupakan tujuan pemerintahan daerah. Sebagai bagian dari Pemerintah, Pemerintahan daerah bertanggungjawab meningkatkan pelayanan publik berdasar indikator-indikator dalam Standar Pelayanan Minimal pada urusan urusan wajib pemerintah daerah yang terkait dengan kebutuhan dasar masyarakat. Prinsip Standar Pelayanan Minimal berbeda dengan prinsip dalam UU Nomor 25 tahun 2009 tentang Pelayanan Publik yang cenderung menekankan pada aspek standar penyediaan barang dan jasa publik yang lebih berorientasi pada terwujudnya good 
governance. Standar Pelayanan Minimal ini berorientasi pada terwujudnya kesejahteraan masyarakat sebagai salah satu tujuan bernegara. Filosofi standar pelayanan minimal ini adalah adanya peningkatan mutu dan akses masyarakat terhadap pelayanan publik pemerintah yang diwujudkan dalam berbagai indikatorindikatornya. Penyusunan indikator-indikator yang disertai dengan capaian dan tahun target capaiannya selain dimaksudkan untuk mempermudah evaluasi juga mempermudah proses perencanaan dan penganggaran setiap tahunnya. Urusanurusan wajib pemerintah daerah yang terkait dengan kebutuhan dasar harus disusun SPM nya oleh kementrian terkait dan diterapkan oleh pemerintah daerah meliputi pendidikan, kesehatan, pekerjaan umum dan tata ruang, perumahan dan pemukiman, ketentraman, ketertiban umum dan perlindungan masyarakat, dan sosial. Urusan-urusan pemerintah ini berdasarkan hasil kajian yang telah dilakukan memberikan hasil bahwa SPM-SPM pada urusan-urusan tersebut merupakan pelaksanaan lebih lanjut dari ketentuan konstitusi UUD 1945, sehingga penyusunan dan penerapan SPM mempunyai landasan konstitutional yang jelas.

Kata Kunci: Standar Pelayanan Minimal; Pelayanan Publik; Konstitusi; Konstitusionalitas

\section{A. PENDAHULUAN}

Pembukaan Undang-Undang Dasar Negara Republik Indonesia Tahun 1945 mengamanatkan bahwa tujuan didirikanya Negara Kesatuan Republik Indonesia di antaranya adalah untuk memajukan kesejahteraaan umum dan mencerdaskan kehidupan bangsa. Mewujudkan kesejahteraan umum akan membawa konsekuensi bahwa negara wajib memenuhi hak dan menjamin ketersediaan kebutuhan dasar setiap warga negara dan penduduknya. Dalam konteks negara Indonesia yang desentralistik, kewajiban untuk memenuhi ini juga harus dilaksanakan oleh pemerintah daerah yang penyelenggaraanya memang dimaksudkan untuk mempercepat terwujudnya kesejahteraan masyarakat melalui peningkatan pelayanan, pemberdayaan, peran serta masyarakat, serta peningkatan daya saing daerah dengan memperhatikan prinsip demokrasi, pemerataan, keadilan dan kekhasan suatu daerah dalam sistem negara kesatuan republik Indonesia.

Dalam sistem desentralistik, negara harus mampu menjamin kesamaan akses bagi semua warganegara dan penduduk terhadap pelayanan publik khususnya pelayanan dasar di manapun berada. Untuk mewujudkan hal tersebut, diperlukan adanya standardisasi pelayanan secara nasional yang di dalamnya juga harus tetap memberikan ruang bagi daerah untuk mengambil diskresi dalam rangka merespon kebutuhan pelayanan dasar. Dengan kata lain diperlukan kemampuan untuk menjaga keseimbangan antara keinginan untuk melakukan standarisasi dan keinginan untuk memberikan diskresi (Dwiyatno, 2010: 4).

Guna memastikan terpenuhinya standar capaian dalam bidang layanan tertentu serta mewujudkan adanya kesamaan kualitas dan akses terhadap layanan tersebut di semua daerah otonom, maka diperlukan adanya indikator-indikator 
yang jelas sebagai tolak ukur pelayanan dan disertai dengan target waktu pencapaianya sehingga pencapaianya akan terukur secara obyektif.

Indikator-indikator tersebut, dalam undang-undang pemerintahan daerah disebut sebagai standar pelayanan minimal, yang merupakan ketentuan tentang jenis dan mutu pelayanan dasar yang merupakan urusan wajib daerah yang berhak diperoleh setiap warga secara minimal. Standar pelayanan secara garis besar terbagi dalam dua sektor, yaitu dalam wilayah privat/swasta/bisnis dan standar pelayanan dalam wilayah publik/pemerintah. Dalam wilayah privat di antaranya adalah Standar Nasional Indonesia (SNI), sementara dalam wilayah publik dikenal adanya Standar Pelayanan yang diatur dalam UU Nomor 25 Tahun 1999 tentang Pelayanan Publik, Standar Pelayanan Mininal (SPM), dan Norma Standar Perilaku dan Kriteria (NSPK) yang diusung oleh undang-undang Nomor 32 Tahun 2004 jo UU Nomor 23 Tahun 2014 Tentang Pemerintahan Daerah.

Standar pelayanan minimal ini dimaksudkan untuk melengkapi berbagai jenis standar yang ada di sektor publik yang diharapkan akan menjadi menjadi tolak ukur bagi kinerja penyelenggaraan urusan pemerintahan wajib daerah yang berkaitan dengan pelayanan dasar kepada masyarakat. Menurut Oentarto, standar pelayanan minimal memiliki nilai yang sangat strategis baik bagi pemerintah daerah maupun bagi masyarakat (konsumen). Pertama, bagi pemerintah daerah SPM dapat dijadikan tolak ukur (benchmark) dalam penentuan biaya yang diperlukan untuk membiayai penyediaan pelayanan. Kedua, bagi masyarakat SPM dapat dijadikan sebagai acuan kualitas dan kuantitas suatu pelayanan publik yang disediakan oleh pemerintah daerah (Oentarto et.al., 2004: 173)

Standar pelayanan merupakan ukuran yang dibakukan dalam penyelenggaraan pelayanan publik sebagai pedoman yang wajib ditaati dan dilaksanakan oleh penyelenggara pelayanan, dan menjadi pedoman bagi penerima pelayanan dalam proses pengajuan permohonan, serta sebagai alat kontrol masyarakat dan/atau penerima layanan atas kinerja penyelenggara pelayanan (Rifai, 2016: 28). Untuk mewujudkan hal tersebut penyediaan pelayanan publik tersebut harus disesuaikan dengan asas-asas umum pemerintah dalam memberikan perlindungan kepada setiap warga negara dan penduduk dari penyalahgunaan wewenang di dalam penyelenggaraan pelayanan publik (Nugroho, 2016: 254).

Standar Pelayanan Minimal (SPM) merupakan kebutuhan dasar warga negara, yakni kebutuhan fisiologis yang apabila tidak terpenuhi akan mengakibatkan warga negara hidup tidak layak atau bahkan bisa meninggal secara sia sia (Hendrawan 2014: 368). Konsep Standar pelayanan minimal sangat berbeda dengan konsep standar pelayanan yang biasanya terkait langsung dengan 'tata cara' atau 'prosedur' pelayanan kepada masyarakat sebagaimana dimaksud pada Undang-Undang Nomor 25 tahun 2009 tentang Pelayanan Publik. Hal ini karena SPM terkait dengan jenis dan mutu pelayanan dasar yang merupakan urusan wajib daerah yang berhak 
diperoleh warga secara minimal. Pengertian tersebut lebih menekankan pada aspek jenis dan mutu pelayanan dasar bukan kepada 'tata cara melayani' masyarakat pengguna layanan dengan subyek sasarannya adalah pemerintah daerah.

Dalam pengertian standar pelayanan minimal itu sendiri terkandung dua konsep utama yaitu: "tolak ukur penyediaan layanan bagi penyedia layanan" dan "acuan mengenai kualitas dan kuantitas layanan bagi pengguna layanan". Adapun yang dimaksud dengan konsep tolak ukur penyediaan layanan adalah kondisi optimal yang dapat dicapai oleh penyedia layanan (pemerintah daerah) yang ditentukan oleh sumberdaya yang dimilikinya (sumberdaya manusia, perlengkapan, dan pembiayaan dan sumberdaya pendukung lainnya). Sementara konsep acuan mengenai kualitas dan kuantitas layanan bagi pengguna layanan (masyarakat) adalah kondisi minimal yang dapat diperoleh dari penyedia layanan (pemerintah daerah) terkait pelayanan publik yang diberikan (Insani: 2010: 34).

Dengan demikian "minimal” dalam pengertian standar pelayanan minimal merupakan kondisi minimal dari sudut pandang masyarakat tetapi mengandung arti "optimal" dari sudut pandang aparat pemerintah daerah. Dengan perkataan lain, bahwa standar pelayanan minimal merupakan peristilahan dari sudut pandang masyarakat sebagai pengguna layanan terhadap kualitas dan kuantitas yang dapat diterima dari pemerintah daerah sebagai penyedia pelayanan publik.

Berbagai penelitian terhadap Standar Pelayanan Minimal telah banyak dilakukan, baik dari perspektif anggaran maupun kebijakan. Penelitian tentang Analisis Pembiayaan Kesehatan Daerah Program Kesehatan Ibu dan Anak (KIA) Berdasarkan Standar Pelayanan Minimal (SPM) (Wijaya: 2010) dan Penelitian tentang berapa besar biaya yang diperlukan untuk penanggulangan gizi buruk dari Kabupaten Sambas dan bagaimana pendapat stake holder tentang pembiayaan program penanggulangan gizi buruk (Gusmasi: 2008) adalah contohnya. Sementara itu dari perspektif kebijakan terdapat penelitian tentang Pengaruh Implementasi Kebijakan Standar Pelayanan Minimal (SPM) Kesehatan Terhadap Efektifitas Pelaksanaan Program Kesehatan Dasar (Kania: 2011), Efektifitas Penerapan Standar Pelayanan Minimal Bidang Kesehatan untuk Peningkatan Kualitas Pelayanan Kesehatan (Khozin: 2010) dan Pelaksanaan kebijakan Standar Pelayanan (Dwiyatno: 2010: 4).

Penerapan SPM menjadi menjadi tanggung jawab pemerintah daerah sebagai bagian dari Negara Kesatuan Republik Indonesia. Artinya, secara substansial keberadaan SPM ini berada dalam wilayah hukum, khususnya Hukum Tata Negara maupun Hukum Administrasi Negara. Walau masih terbilang sedikit, salah satu penelitian hukum yang menjadikan SPM sebagai kajian pada ranah Tata Negara dan Administrasi Negara adalah Efektivitas Pengaturan Standar Pelayanan Minimal Dalam Perspektif Desentralisasi di Indonesia (Kurniawan: 2011). Dalam artikel ini penulis mengkaji tentang Konstitusionalitas Standar Pelayanan Minimal dengan 
tujuan untuk melihat adakah dasar konstitusi dari pengaturan dan penerapan Standar Pelayanan Minimal dan bagaimana pengaturan SPM ini pada masa yang akan datang.

\section{B. METODOLOGI PENELITIAN}

Penelitian ini merupakan penelitian yuridis normatif dengan aspek penelitian pada sinkronisasi hukum. Obyek penelitiannya adalah bagaimana hukum positif yang mengatur tentang SPM serasi atau sinkron satu sama lainnya (Zainudin, 2014: 27). Sinkronisasi dilakukan terhadap beberapa bahan hukum primer yang meliputi bahan hukum yang mempunyai kekuatan mengikat, yaitu:

1. Undang-undang Dasar Negara Republik Indonesia Tahun 1945;

2. Undang-undang Nomor 32 tahun 2004 jo UU Nomor 32 tahun 2014 tentang Pemerintahan Daerah;

3. Peraturan Pemerintah Nomor 65 tahun 2005 tentang Pedoman Penyusunan dan Penerapan Standar Pelayanan Minimal;

4. Peraturan Menteri Kesehatan Republik Indonesia Nomor 43 Tahun 2016 Tentang Standar Pelayanan Minimal Bidang Kesehatan;

5. Peraturan Menteri Pekerjaan Umum Nomor: 14 /Prt/M/2010 tentang Standar Pelayanan Minimal Bidang Pekerjaan Umum dan Penataan Ruang

6. Peraturan Menteri Pendidikan Nasional Republik Indonesia Nomor 15 Tahun 2010 Tentang Standar Pelayanan Minimal Pendidikan Dasar Di Kabupaten/Kota;

7. Peraturan Menteri Negara Perumahan Rakyat Nomor 16 Tahun 2010 tentang Petunjuk Teknis Perencanaan Pembiayaan Pencapaian Standar Pelayanan Minimal Bidang Perumahan Rakyat Daerah Provinsi;

8. Keputusan Menteri Sosial Republik Indonesia Nomor 80 Tahun 2010 tentang Panduan Perencanaan Pemibiayaan Pencapaian Standar Pelayanan Minimal (SPM) Bidang Sosial Daerah Provinsi dan Daerah Kabupaten/Kota

Data data yang telah terkumpul selanjutnya dianalisis berdasarkan asas hukum, teori/pendapat, maupun ketentuan peraturan perundang-undangan. Konstitusionalitas dalam penelitian ini diartikan sebagai kesesuaian berbagai kebijakan SPM dengan ketentuan konstitusi

\section{PEMBAHASAN}

Pengaturan mengenai SPM sudah ada sejak UU Nomor 22 Tahun 1999 Tentang Pemerintahah daerah, UU Nomor 32 Tahun 2004, dan juga UU Nomor 23 Tahun 2014 Tentang Pemerintahan Daerah. UU Nomor 32 tahun 2004 jo UU Nomor 23 tahun 2014 tentang Pemerintah Daerah secara lebih khusus mengatur tentang standar pelayanan minimal ini. Dalam ketentuan pasal 11 (4) UU Nomor 32 tahun 2004 diyatakan bahwa "Penyelenggaraan Urusan Pemerintahan yang bersifat wajib yang berpedoman pada standar pelayanan minimal dilaksanakan secara bertahap dan ditetapkan oleh pemerintah". Sementara itu, dalam UU Nomor 23 tahun 2014 dinyatakan bahwa, "Pelaksanaan pelayanan dasar pada urusan pemerintahan wajib 
yang berkaitan dengan pelayanan dasar sebagaimana dimaksud dalam ayat (1) berpedoman pada standar pelayanan minimal yang akan ditetapkan oleh Pemerintah"

Perubahan UU tersebut berimplikasi kepada lingkup urusan yang harus ada standar pelayanan minimalnya. Dalam UU Nomor 32 Tahun 2014 SPM dipersyaratkan bagi 26 urusan pemerintahan yang bersifar wajib, sementara dalam ketentuan UU Nomor 32 tahun 2014 menjadi terbatas, karena hanya diperuntukkan bagi urusan wajib yang terkait dengan pelayanan dasar. Pelayanan dasar sendiri merupakan pelayanan publik untuk memenuhi kebutuhan dasar warga negara yang meliputi pendidikan, kesehatan, pekerjaan umum dan tata ruang, perumahan dan pemukiman, Ketentraman, ketertiban masyarakat dan pelindungan masyarakat, dan sosial (Pasal 12 ayat (1) UU Nomor 23 Tahun 2014). Perbandingan urusan tersebut bisa dilihat dari table dibawah ini:

Tabel 1.1

Perbandingan Jenis Urusan dalam UU Nomor 32 tahun 2004 dengan UU 23 tahun 2014

\begin{tabular}{|c|c|c|}
\hline Indikator & UU 32 tahun 2004 & UU 23 tahun 2014 \\
\hline Klasifikasi & $\begin{array}{l}\text { 1. UP Absolut } \\
\text { 2. UP Concurent } \\
\text { a. Wajib } \\
\text { b. Pilihan }\end{array}$ & $\begin{array}{l}\text { 1. UP Absolut } \\
\text { 2. UP Concurent } \\
\text { a. Wajib } \\
\text { 1) Terkait pelayanan dasar } \\
\text { 2) Tidak terkait pelayanan } \\
\text { dasar } \\
\text { b. Pilihan } \\
\text { 3. UP Umum }\end{array}$ \\
\hline $\begin{array}{l}\text { Urusan } \\
\text { Pemerintahan } \\
\text { Absolut }\end{array}$ & $\begin{array}{l}\text { 1. Politik Luar } \\
\text { Negeri } \\
\text { 2. Pertahanan } \\
\text { 3. Keamanan } \\
\text { 4. Moneter/Fiskal } \\
\text { 5. Peradilan } \\
\text { 6. Agama }\end{array}$ & $\begin{array}{l}\text { 1. Politik Luar Negeri } \\
\text { 2. Pertahanan } \\
\text { 3. Keamanan } \\
\text { 4. Moneter/Fiskal } \\
\text { 5. Peradilan } \\
\text { 6. Agama }\end{array}$ \\
\hline $\begin{array}{l}\text { Urusan } \\
\text { Pemerintahan } \\
\text { Concurent } \\
\text { Yang Wajib }\end{array}$ & $\begin{array}{l}\text { UP Wajib: } \\
\text { 1. Pendidikan } \\
\text { 2. Kesehatan } \\
\text { 3. Pekerjaan } \\
\text { Umum } \\
\text { 4. Perumahan } \\
\text { Rakyat } \\
\text { 5. Penataan Ruang } \\
\text { 6. Perencanaan } \\
\text { 7. Pembangunan } \\
\text { 7. Perhubungan } \\
\text { 8. Lingkungan }\end{array}$ & $\begin{array}{l}\text { Wajib dan Kepentingan dasar: } \\
\text { 1. Pendidikan } \\
\text { 2. Kesehatan } \\
\text { 3. Pekerjaan Umum dan Penataan } \\
\text { Ruang } \\
\text { 4. Perumahan Rakyat dan } \\
\text { Kawasan Permukiman } \\
\text { 5. Ketenteraman, Ketertiban } \\
\text { Umum, dan Pelindungan } \\
\text { Masyarakat } \\
\text { 6. Sosial }\end{array}$ \\
\hline
\end{tabular}




\begin{tabular}{|c|c|c|}
\hline & $\begin{array}{l}\text { Hidup } \\
\text { 9. Pertanahan } \\
\text { 10. Kependudukan } \\
\text { dan Catatan } \\
\text { Sipil } \\
\text { 11. Pemberdayaan } \\
\text { Perempuan } \\
\text { 12. Keluarga } \\
\text { Berencana dan } \\
\text { Keluarga } \\
\text { Sejahtera } \\
\text { 13. Sosial } \\
\text { 14. Tenaga Kerja } \\
\text { 15. Koperasi dan } \\
\text { Usaha Kecil dan } \\
\text { Menengah } \\
\text { 16. Penanaman } \\
\text { Modal } \\
\text { 17. Kebudayaan } \\
\text { 18. Pemuda dan } \\
\text { Olah Raga } \\
\text { 19. Kesatuan } \\
\text { Bangsa dan } \\
\text { Politik Dalam } \\
\text { Negeri } \\
\text { 20. Pemerintahan } \\
\text { Umum } \\
\text { 21. Kepegawaian } \\
\text { 22. Pemberdayaan } \\
\text { Masyrakat dan } \\
\text { Desa } \\
\text { 23. Statistik } \\
\text { 24. Arsip } \\
\text { 25. Komunikasi dan } \\
\text { Informasi } \\
\end{array}$ & $\begin{array}{l}\text { Wajib dan bukan Kepentingan } \\
\text { dasar: } \\
\text { 1. Tenaga Kerja } \\
\text { 2. Pemberdayaan Perempuan dan } \\
\text { Pelindungan Anak } \\
\text { 3. Pangan } \\
\text { 4. Pertanahan } \\
\text { 5. Lingkungan Hidup } \\
\text { 6. Administrasi Kependudukan } \\
\text { dan Pencatatan Sipil } \\
\text { 7. Pemberdayaan Masyarakat dan } \\
\text { Desa } \\
\text { 8. Pengendalian Penduduk dan KB } \\
\text { 9. Perhubungan } \\
\text { 10. Komunikasi dan Informatika; } \\
\text { 11. Koperasi, Usaha Kecil dan } \\
\text { Menengah } \\
\text { 12. Penanaman Modal } \\
\text { 13. Kepemudaan dan Olah Raga } \\
\text { 14. Statistik } \\
\text { 15. Persandian } \\
\text { 16. Kebudayaan } \\
\text { 17. Perpustakaan } \\
\text { 18. Kearsipan. }\end{array}$ \\
\hline $\begin{array}{l}\text { Urusan } \\
\text { Pemerintahan } \\
\text { Conkuren } \\
\text { yang Pilihan }\end{array}$ & $\begin{array}{l}\text { 1. } \text { Kelautan dan } \\
\text { Perikanan } \\
\text { 2. Pariwisata } \\
\text { 3. Pertanian } \\
\text { 4. Kehutanan } \\
\text { 5. Energi dan } \\
\text { sumber daya } \\
\text { mineral } \\
\text { 6. Perdagangan } \\
\text { 7. Perindustrian } \\
\text { 8. Transmigrasi }\end{array}$ & $\begin{array}{l}\text { 1. Kelautan dan Perikanan } \\
\text { 2. Pariwisata } \\
\text { 3. Pertanian } \\
\text { 4. Kehutanan } \\
\text { 5. Energi dan Sumber } \\
\text { Mineral } \\
\text { 6. Perdagangan } \\
\text { 7. Perindustrian } \\
\text { 8. Transmigrasi }\end{array}$ \\
\hline $\begin{array}{l}\text { Urusan } \\
\text { pemerintahan } \\
\text { Umum }\end{array}$ & Tidak dikenal & $\begin{array}{l}\text { 1. Ideologi Pancasia, UUD } 45 \text {, } \\
\text { Kebhinnekaan } \\
\text { 2. Menjalin hubungan yang serasi }\end{array}$ \\
\hline
\end{tabular}




\begin{tabular}{|l|l|l|}
\hline & $\begin{array}{l}\text { antar suku, agama, Ras, antar } \\
\text { golongan } \\
\text { 3. Fasilitasi kehidupan demokrasi }\end{array}$ \\
\hline
\end{tabular}

Konsep tentang urusan wajib sendiri telah mengalami penyempitan makna, yang mana dalam penjelasan UU Nomor 32 tahun 2004 dinyatakan bahwa urusan wajib adalah urusan yang sangat mendasar yang berkaitan dengan hak dan pelayanan dasar warga negara antara lain:

1. Perlindungan hak konstitusional

2. Perlindungan kepentingan nasional, kesejahteraan masyakat, ketentraman dan ketertiban umum dalam kerangka menjaga keutuhan NKRI

3. Pemenuhan komitmen nasional yang berhubungan dengan perjanjian dan konvensi internasional

Sementara itu dalam ketentuan umum UU Nomor 23 tahun 2014 disebutkan bahwa "urusan wajib adalah urusan yang wajib dilaksanakan oleh pemerintah daerah". Namun dalam penjelasan umumnya dinyatakan bahwa untuk ".... urusan wajib yang terkait dengan pelayanan dasar ditentukan standar pelayanan mininal untuk menjamin hak konstitusional masyarakat". Berdasarkan pada ketentuan 2 UU Pemerintahan Daerah tersebut, maka konsepsi urusan wajib pemerintahan dilaksanakan dalam kerangka pemenuhan hak konstitusional warga negara.

Penuangan HAM dalam UUD 1945 telah melahirkan nomenklatur Hak Konstitusional (Constitusional Right) yaitu hak asasi yang dijamin oleh konstitusi negara. Oleh karenanya, negara wajib secara simultan melindungi dan mewujudkan hak konstitusional warganya. Perkembangan terpenting dari pengaturan ini adalah bahwa negara memikul tanggungjawab besar untuk melundungi, menghormati, dan menegakkan hak konstitusi demi mempertahankan integritas martabat menusia yang menjadi amanat UUD 1945. Selain itu, penuangan hak hak asasi manusia dalam UUD 1945 sebagai The Supreme Law of Land merupakan bentuk pengakuan terhadap Kesadaran sosialis manusia sebagai mahluk yang bermartabat. Telepas dari adanya kelompok yang berpandangan bahwa UUS 1945 tidak memberikan jaminan atas HAM yang komprehensif dan hanya memberikan jaminan pokoknya saja (El Muhtaj, 2009: 94-95).

Hak Asasi Manusia (HAM) Merupakan hak yang melekat pada diri setiap pribadi manusia tanpa memandang suku, adat istiadat maupun kewarganegaraan seseorang. Oleh karena itu, menjadi berbeda antara HAM dengan hak-hak warganegara yang khusus diberikan kepada warga negara tertentu. Pada konteks Indonesia, karena beberapa ketentuan dalam HAM telah tercantum dengan tegas dalam UUD 1945, maka secara resmi telah menjadi hak konstitusional setiap warga negara, namun demikian harus difahami bahwa tidak semua hak konstitusional identik dengan HAM. Terdapat hak konstitusional warga negara yang tidak termasuk HAM, misalnya hak untuk menduduki jabatan dalam pemerintahan. Hak ini merupakan hak konstitusional warga negara (Citizen Constitutional Right) yang 
hanya dimiliki oleh warga negara Indonesia saja, sementara warga negara asing betapapun telah berdomisili di Indonesia tidak bisa menuntut pemenuhan hak tersebut. Berdasarkan pemahaman tersebut, maka tidak semua hak konstitusi adalah HAM, namun dapat dikatakan bahwa semua HAM juga sekaligus merupakan hak konstitusi (Asshiddiqie, Kumpulan Tulisan halaman: 547). Pada posisi lain, Mahfud MD menekankan perbedaan antara HAM dengan Hak Asasi Warganegara (HAW). HAM mendasarkan diri pada paham bahwa secara kodrati manusia di manapun berada mempunyai hak-hak bawaan yang tidak dapat dipindah, diambil atau dialihkan. Sedangkan HAW hanya mungkin diperoleh karena seseorang memiliki status warga negera (HAM partikularistik) (Mahfud MD, 107-108).

Konstitusi kita menggunakan istilah HAW dan bukan HAM. Hal ini karena suatu hak kemanusiaan sebenarnya baru menjadi permasalahan apabila berada dalam lingkungan manusia lainya. Dalam kerangka pemikiran inilah maka rumusan perlindungan hak-hak kemanusiaan di dalam UUD dijelmakan dalam hak warga negara dan mengenai kedudukan penduduk. Sebagaimana disebutkan dalam penjelasan BAB X UUD 1945, bahwa rumusan HAM adalah terkait dengan hasrat bangsa indonesia untuk membangun negara yang bersifat demokratis dan yang hendak menyelenggarakan keadilan sosial dan kemanusiaan (Wahyono, 1983: 1011).

Berdasarkan perbedaan pengertian antara warga negara dengan penduduk (Pandoyo, 2003) UUD 1945 mengatur pembedaan perlakuan, khususnya mengenai perlindungan terhadap WN dan perlindungan terhadap penduduk. Bagi WNI diberikan hak-hak khusus dan tertentu dan negara wajib melindungi hak-hak tersebut yang disebut dengan hak konstitusional warga negara. Hak konstitusional warga negara meliputi hak asasi manusia dan hak asasi warganegara yang dijamin dalam UUD 1945 dan berlaku bagi setiap WNI. Hal ini dapat dilihat dari rumusanya yang menggunakan frasa "setiap orang", "segala warga negara", "tiap tiap warga negara", atau "setiap warga negara" yang menunjukkan bahwa hak konstitusional dimiliki oleh setiap individu warga negara tanpa pembedaan, baik berdasarkan suku, agama, keyakinan politik, ataupun jenis kelamin. Hak hak tersebut diakui dan dijamin untuk setiap warga negara.

Sebagai implementasi dari ketentuan konstitusi untuk memajukan kesejahteraan umum maka dibentuklah pemerintah daerah sebagaimana diatur dalam dari UU Nomor 32 Tahun 2004 jo UU Nomor 23 Tahun 2014 Tentang Pemerintah daerah. Sebagai pelaksanaan ketentuan diterbitkanlah PP Nomor 65 Tahun 2005 Tentang Pedoman Penyusunan dan Penerapan SPM sebagai pedoman bagi kementrian untuk menyusun SPM dan bagi daerah untuk menerapkan SPM. Sampai dengan akhir tahun 2010 pemerintah melalui Kementrian/Lembaga Negara telah menyusun 13 SPM di berbagai bidang sebagai pedoman bagi penerapan oleh daerah (SE Mendagri Nomor: 100/676/SJ). 
Setelah diundangkanya UU Nomor 23 Tahun 2014 Tentang Pemerintahan Daerah, lingkup SPM mengalami penyempitan dari semua urusan wajib daerah menjadi hanya bagi urusan wajib yang terkait dengan kebutuhan dasar. Ruang lingkup SPM ini meliputi 6 bidang, yaitu pendidikan, kesehatan, pekerjaan umum dan tata ruang, Perumahan dan Permukiman, ketentraman, ketertiban umum dan perlindungan masyarakat dan urusan Sosial.

Dari keenam urusan tersebut, hingga saat ini baru ada 5 urusan yang telah ada SPM nya, terlepas dari apakah SPM tersebut sudah kadaluwarsa dan perlu revisi atau tidak. Berikut ini adalah regulasi yang mengatur tentang SPM yang masih berlaku:

1. Peraturan Menteri Kesehatan Republik Indonesia Nomor 43 Tahun 2016 Tentang Standar Pelayanan Minimal Bidang Kesehatan

2. Peraturan Menteri Pekerjaan Umum Nomor: 14/Prt/M/2010 Tentang Standar Pelayanan Minimal Bidang Pekerjaan Umum dan Penataan Ruang

3. Peraturan Menteri Pendidikan Nasional Republik Indonesia Nomor 15 Tahun 2010 Tentang Standar Pelayanan Minimal Pendidikan Dasar Di Kabupaten/Kota

4. Peraturan Menteri Negara Perumahan Rakyat Nomor 16 Tahun 2010 Tentang Petunjuk Teknis Perencanaan Pembiayaan Pencapaian Standar Pelayanan Minimal Bidang Perumahan Rakyat Daerah Provinsi

5. Keputusan Menteri Sosial Republik Indonesia Nomor 80 Tahun 2010 Tentang Panduan Perencanaan Pemibiayaan Pencapaian Standar Pelayanan Minimal (SPM) Bidang Sosial Daerah Provinsi dan Daerah Kabupaten/Kota

Untuk mewujudkan visi peningkatan mutu dan akses warga negara kepada SPM, maka masing masing indikator yang disusun dilengkapi dengan persentase capaian dan target waktu pencapaian yang akan memudahkan pengukurannya. Peraturan Menteri Kesehatan Nomor 741/MENKES/PER/VII/2008 tentang Standar Pelayanan Minimal Bidang Kesehatan di Kabupaten/Kota misalnya, merumuskan indikator SPM Kesehatan dalam 4 bidang layanan yang terbagi dalam 18 cakupan indikator. Indikator dan cakupannya tersebut dapat dilihat dalam tabel berikut:

Tabel 1.2

Indikator Standar Pelayanan Minimal Kesehatan Bidang Layanan

\begin{tabular}{|c|l|l|}
\hline \multicolumn{1}{|c|}{ Indikator } & \multicolumn{1}{|c|}{ Cakupan } & Persentase (\%) \\
\hline \multirow{5}{*}{ Pelayanan Kesehatan Dasar } & Kunjungan Ibu Hamil K4 & $95 \%(2015)$ \\
\cline { 2 - 3 } & $\begin{array}{l}\text { Ibu Hamil dengan Komplikasi } \\
\text { yang Ditangani }\end{array}$ & $80 \%(2015)$ \\
\cline { 2 - 3 } & $\begin{array}{l}\text { Pertolongan Persalinan oleh } \\
\text { Tenaga Kesehatan yang } \\
\text { Memiliki Kompetensi } \\
\text { Kebidanan }\end{array}$ & $90 \%(2015)$ \\
\hline
\end{tabular}




\begin{tabular}{|c|c|c|}
\hline & Pelayanan Ibu Nifas & $90 \%(2015)$ \\
\hline & $\begin{array}{l}\text { Neonatal dengan Komplikasi } \\
\text { yang Ditangani }\end{array}$ & $80 \%(2010)$ \\
\hline & Kunjungan Bayi & $90 \%(2010)$ \\
\hline & $\begin{array}{l}\text { Desa/Kelurahan Universal Child } \\
\text { Immunization (UCI) }\end{array}$ & $100 \%(2010)$ \\
\hline & Pelayanan Anak Balita & $90 \%$ (2010) \\
\hline & $\begin{array}{l}\text { Pemberian Makanan } \\
\text { Pendamping ASI Pada Anak Usia } \\
\text { 6-24 Bulan Keluarga Miskin }\end{array}$ & $100 \%(2010)$ \\
\hline & $\begin{array}{l}\text { Balita Gizi Buruk Mendapat } \\
\text { Perawatan }\end{array}$ & $100 \%(2010)$ \\
\hline & $\begin{array}{l}\text { Penjaringan Kesehatan Siswa } \\
\text { SD dan Setingkat }\end{array}$ & $100 \%(2010)$ \\
\hline & Peserta KB Aktif & $70 \%(2010)$ \\
\hline & $\begin{array}{l}\text { Penemuan dan Penanganan } \\
\text { Penderita Penyakit }\end{array}$ & $100 \%(2010)$ \\
\hline & $\begin{array}{l}\text { Pelayanan Kesehatan Dasar } \\
\text { Masyarakat Miskin }\end{array}$ & $100 \%(2015)$ \\
\hline \multirow[b]{2}{*}{ Pelayanan Kesehatan Rujukan } & $\begin{array}{l}\text { pelayanan kesehatan rujukan } \\
\text { pasien masyarakat miskin }\end{array}$ & $100 \%(2015)$ \\
\hline & $\begin{array}{l}\text { pelayanan gawat darurat level } 1 \\
\text { yang harus diberikan sarana } \\
\text { kesehatan (RS) di } \\
\text { Kabupaten/Kota }\end{array}$ & $100 \%(2015)$ \\
\hline $\begin{array}{l}\text { Penyelidikan Epidemiologi } \\
\text { dan Penanggulangan Kejadian } \\
\text { Luar Biasa /KLB }\end{array}$ & $\begin{array}{l}\text { Cakupan Desa/ Kelurahan } \\
\text { mengalami KLB yang dilakukan } \\
\text { penyelidikan epidemiologi }<24 \\
\text { jam }\end{array}$ & $100 \%(2015)$ \\
\hline $\begin{array}{l}\text { Promosi } \text { Kesehatan dan } \\
\text { Pemberdayaan Masyarakat }\end{array}$ & Cakupan Desa Siaga Aktif & $80 \%(2015)$ \\
\hline
\end{tabular}

Berdasarkan indikator-indikator tersebut di atas, setidaknya dapat menggambarkan dua hal, yaitu pertama bagi daerah adanya target capaian yang jelas pada masing-masing indikator baik menyangkut jumlah \% capaiannya maupun target waktunya. Kedua secara nasional menggambarkan tahapan-tahapan pembangunan bidang kesehatan pada periode tertentu yang harus disesuaikan seiring dengan periode waktunya. Dalam Permenkes ini waktu terakhir capaian indikator adalah tahun 2015, konskuensinya SPM ini hanya berlaku sampai akhir tahun 2015 untuk selanjutnya harus disusun SPM berikutnya. Untuk mewujudkan hal ini maka pada tanggal 31 Agustus 2016, Kementrian Kesehatan telah menerbitkan Peraturan Menteri Kesehatan Republik Indonesia Nomor 43 Tahun 
2016 Tentang Standar Pelayanan Minimal Bidang Kesehatan sebagai pengganti Peraturan Menteri Kesehatan Nomor 741/MENKES/PER/VII/2008 tentang Standar Pelayanan Minimal Bidang Kesehatan di Kabupaten/Kota

Indikator-indikator dalam SPM Kesehatan tersebut di atas, apabila secara kualitas terpenuhi dan dapat dinikmati oleh seluruh masyarakat, maka akan berkontribusi pada upaya pencapaian kesejahteraan masyarakat sebagaimana dicita-citakan dalam konstitusi UUD 1945. Pada ketentuan SPM tersebut apabila dikaji lebih mendalam maka akan ditemukan aspek konstitusionalitasnya. Beberapa ketentuan konstitusi yang mempunyai korelasi erat dengan bidang-bidang kebutuhan dasar yang harus memiliki SPM dapat kita lihat dari uraian sebagai berikut:

\section{Pasal $28 \mathrm{C}$}

1) Setiap orang berhak mengembangkan diri melalui pemenuhan kebutuhan dasarnya, berhak mendapatkan pendidikan dan memperoleh manfaat dari ilmu pengetahuan dan tehnologi, seni dan buaya, semi meningkatkan kualitas hidupnya dan demi kesejahteraan umat manusia.

2) Setiap orang berhak untuk memajukan dirinya dalam memperjuangkan hak nya secara kolektif untuk membangun masyarakat, bangsa dan negaranya"

Ketentuan dalam pasal ini kemudian mendasari penyusunan SPM bidang pendidikan sebagaimana diatur dalam Peraturan Menteri Pendidikan Nasional Nomor 15 Tahun 2010 tentang SPM Pendidikan Dasar di Kabupaten/Kota.

\section{Pasal 28 G}

1) Setiap orang berhak atas perlindungan diri pribadi, keluarga, kehormatan, martabat, dan harta benda yang di bawah kekuasaannya, serta berhak atas rasa aman dan perlindungan dari ancaman ketakutan untuk berbuat atau tidak berbuat sesuatu yang merupakan hak asasi.

2) Setiap orang berhak untuk bebas dari penyiksaan atau perlakuan yang merendahkan derajat martabat manusia dan berhak memperoleh suaka politik dari negara lain.

Ketentuan dalam Pasal 28 G Ini mengatur tentang Perlindungan Pribadi, Keluarga, Kehormatan dan Harkat dan Martabat. Ketentuan Ini diiplementasikan dalam SPM pemerintahan dalam negeri sebagaimana diatur dalam Peraturan Menteri Dalam Negeri Nomor 69 Tahun 2012 tentang Perubahan Atas Peraturan Menteri Dalam Negeri Nomor 62 Tahun 2008 tentang Standar Pelayanan Minimal Bidang Pemerintahan Dalam Negeri di Kabupaten/Kota. Jenis pelayanannya meliputi:

1. Pelayanan dokumen kependudukan;

2. Pemeliharaan ketertiban umum, ketentraman masyarakat dan perlindungan masyarakat; dan

3. Penanggulangan bencana kebakaran. 
Pada masing-masing jenis tersebut dilengkapi dengan jenis pelayanan dasar, indikator kinerja, nilai SPM, batas waktu pencapaian, dan satuan kerja/lembaga penanggung jawab.

\section{Pasal 28H}

1) Setiap orang berhak hidup sejahtera lahir dan batin, bertempat tinggal, dan medapatkan lingkungan hidup baik dan sehat serta berhak memperoleh pelayanan kesehatan

2) Setiap orang mendapat kemudahan dan perlakuan khusus untuk memperoleh kesempatan dan manfaat yang sama guna mencapai persamaan dan keadilan

3) Setiap orang berhak atas jaminan sosial yang memungkinkan pengembangan dirinya secara utuh sebagai manusia yang bermartabat.

Ketentuan pasal ini bisa menjadi dasar bagi penyusunan SPM Perumahan, (Peraturan Menteri Perumahan Rakyat Nomor 22 Tahun 2008 tentang SPM Bidang Perumahan Rakyat Daerah Provinsi dan Daerah Kabupaten/Kota), SPM Pekerjaan Umum (Peraturan Menteri Pekerjaan Umum Nomor 14/PRT/M/2010 tentang SPM Bidang Pekerjaan Umum dan Penataan Ruang), SPM Kesehatan (Peraturan Menteri Kesehatan RI No. 741/Menkes/Per/Vii/2008 tentang Standar Pelayanan Minimal Bidang Kesehatan di Kabupaten/Kota), dan SPM sosial (Peraturan Menteri Sosial Nomor 129 Tahun 2008 tentang SPM Bidang Sosial Daerah Provinsi dan Daerah Kabupaten/Kota).

Pasal 31

1) Setiap warga negara berhak mendapat pendidikan

2) Setiap warga negara wajib mengikuti pendidikan dasar dan pemerintah wajib membiayainya

3) Pemerintah mengusahakan dan menyelenggarakan satu sistem pendidikan nasional, yang meningkatkan keimanan dan ketakwaan serta akhlak mulia dalam rangka mencerdaskan kehidupan bangsa, yang diatur dengan undang-undang

4) Negara memprioritaskan anggaran pendidikan sekurang-kurangnya dua puluh persen dari anggaran pendapatan dan belanja negara serta dari anggaran pendapatan dan belanja daerah untuk memenuhi kebutuhan penyelenggaraan pendidikan nasional

5) Pemerintah memajukan ilmu pengetahuan dan teknologi dengan menjunjung tinggi nilai-nilai agama dan persatuan bangsa untuk kemajuan peradaban serta kesejahteraan manusia

Ketentuan pasal 31 ini secara khusus mengatur tentang Pendidikan Nasional yang merupakan urusan pemerintahan yang bersifat wajib dan terkait dengan pelayanan dasar. Standar Pelayanan Minimal Pendidikan (Peraturan Menteri 
Pendidikan Nasional Republik Indonesia Nomor 15 Tahun 2010 tentang Standar Pelayanan Minimal Pendidikan Dasar di Kabupaten/Kota) merupakan implementasi dari Hak Konstitusional warga negara untuk mendapatkan pendidikan.

\section{Pasal 34}

1) Fakir miskin dan anak-anak yang terlantar dipelihara oleh negara

2) Negara mengembangkan sistem jaminan sosial bagi seluruh rakyat dan memberdayakan masyarakat yang lemah dan ticlak mampu sesuai dengan martabat kemanusiaan

3) Negara bertanggung jawab atas penyediaan fasilitas pelayanan kesehatan dan fasilitas pelayanan umum yang layak

4) Ketentuan lebih lanjut mengenai pelaksanaan pasal ini diatur dalam undang-undang

Ketentuan dalam pasal-pasal tersebut, mengatur tentang sistem jaminan sosial, penyediaan fasilitas kesehatan dan fasilitas umum yang layak. Ketentuan ini menjadi dasar bagi penyusunan SPM Kesehatan (Peraturan Menteri Kesehatan RI No. 741/Menkes/Per/VII/2008 Tentang Standar Pelayanan Minimal Bidang Kesehatan Di Kabupaten/Kota), dan SPM sosial (Peraturan Menteri Sosial Nomor 129 Tahun 2008 tentang SPM Bidang Sosial Daerah Provinsi dan Daerah Kabupaten/Kota)

Berdasarkan uraian tersebut, dapat kita ambil kesimpulan bahwa SPM yang disusun untuk urusan wajib yang terkait dengan pelayanan dasar mempunyai rujukan dalam ketentuan konstitusi UUD 1945. Atau dengan kata lain SPM tersebut merupakan implementasi dari hak-hak konstitusional, sehingga melaksanakan ketentuan SPM pada hakekatnya adalah melaksanakan hak konstitusional warga negara.

Dalam perspektif yang lebih luas, indikator-indikator dalam SPM tersebut bisa dijadikan tafsir dari makna kesejahteraan masyarakat yang dicita-citakan dalam pembukaan UUD 1945. Hal ini karena berbagai ketentuan dalam Peraturan Menteri tersebut disusun berdasarkan PP Nomor 65 tahun 2005 tentang Pedoman Penyusunan dan Penerapan Standar Pelayanan Minimal. Peraturan Pemerintah ini melaksanakan ketentuan yang melaksanakan perintah Pasal 14 ayat 3 UU Nomor 32 tahun 2004 tentang Pemerintahan daerah. Sementara itu, UU Nomor 32 Tahun 2004 disusun untuk melaksanakan ketentuan Pasal 18, Pasal 18 A dan Pasal 19B UUD 1945. Lebih lanjut dapat disampikan bahwa ketentuan dalam batang tubuh UUD 1945 merupakan penjabaran dari ketentuan pembukaan UUD 1945.

Berdasarkan pemahaman tersebut di atas, sangat jelas konstruksi SPM dalam kaitannya dengan Konstitusi 1945 atau konstitusionalitasnya SPM. Oleh karenanya dapat dinyatakan bahwa implementasi 5 SPM dalam Negera Kesatuan Republik Indonesia adalah sebuah keniscayaan konstitusi. 


\section{KESIMPULAN}

Standar Pelayanan minimal merupakan salah satu parameter yang disusun oleh pemerintah untuk menjamin standar pelayanan kepada masyarakat. Disamping ketentuan dalam UU Nomor 25 tahun 2009 tentang Pelayanan Publik, masih terdapat dua standar lagi yang lahir dalam bingkai UU Pemerintahan daerah, yaitu Norma Standar, Perilaku, dan Kriteria (NSPK) dan Standar Pelayanan Minimal. Perbedaannya adalah bahwa NPSK diperuntukkan bagi penyelenggaraan urusan wajib yang tidak terkait dengan kebutuhan dasar masyarakat, sementara SPM diperuntukkan bagi penyelenggaraan urusan wajib yang terkait dengan kebutuhan dasar masyarakat. Kedua standar ini diusung oleh Undang-Undang Nomor 32 Tahun 2004 jo UU Nomor 23 Tahun 2014 Tentang Pemerintahan Daerah.

Prinsip dasar SPM pada orientasinya tidak hanya memperjuangkan kualitas pelayanan semata, namun juga memperjuangkan kuantitas sehingga bisa dinikmati oleh semua masyarakat indonesia. Berbagai urusan pemerintahan yang telah diperintahkan penyusunan SPM-nya ternyata mempunyai dasar yang kuat dalam ketentuan konstitusi UUD 1945. Artinya, pengaturan dan penerapan SPM sesungguhnya merupakan implemantasi dari ketentuan konstitusi. Hanya saja, berbagai pengaturan tentang SPM itu sendiri sudah seharusnya dilakukan revisi, pertama karena telah berubahnya nomenklatur urusan pemerintahan; kedua banyak SPM yang telah kadalaluwarsa waktunya, maksudnya waktu pencapaian standarnya telah terlewati; dan ketiga perlunya komitmen pemerintah dan pemerintah daerah untuk menjamin pemenuhan SPM tersebut.

\section{DAFTAR PUSTAKA}

\section{a. Buku}

Asshiddiqie, Jimly (2007). Hak Konstitusional Perempuan Dan Tantangannya, Perempuan Dan Konstitusi Di Era Otonomi Daerah Tantangan Dan Penyikapan Bersama, Jakarta. Jakarta: PT Ichtiar Baru, Van Hoeve.

Dwiyanto, Agus (2010). Manajemen Pelayanan Publik. Yogyakarta: Gadjah Mada University Press.

Insani, Itsyadi (t.t.). "Kebijakan Standar Pelayanan Minimal di Indonesia" dalam Bunga Rampai Administrasi Publik: Dimensi Pelayanan Publik Dan Tantangannya Dalam Administrasi Negara (Publik) Di Indonesia. Jakarta: Lembaga Administrasi Negara.

MD, Mahfud (1999). Hukum Dan Pilar Demokrasi. Jakarta: Gama Media.

Muhtaj, Majda El (2009). Hak Asasi Manusia Dalam Konstitusi Indonesia, dari UUD 1945 Sampai Dengan Amandemen UUD 1945. Jakarta: Prenada Media.

Pandoyo, Hestu Cipto (2003). Hukum Tata Negara, Kewarganegaraan dan HAM. Yogyakarta: Universitas Atma Jaya.

Wahyono, Padmo (1983). Indonesia Berdasarkan Hukum. Jakarta: Ghalia Indonesia. 


\section{b. Jurnal}

Hendarwan et. al. (2015). Analisis Implementasi Standar Pelayanan Minimal Bidang Kesehatan Kabupaten/Kota. Jurnal Ekologi Kesehatan, 14(4).

Kania, Ikeu (2010). Pengaruh Implementasi Kebijakan SPM Bidang Kesehatan Terhadap Efektifitas Pelaksanaan Program Kesehatan Dasar Pada Dinas Kesehatan Kabupaten Garut. Indonesion Journal of Dialectic (IJAT), 1(2).

Rifai, M. et. al. (2016). Implemantasi Kebijakan SPM Bidang Kesehatan Idi Puskesmas Kabupaten Kuningan Provinsi Jawa Barat. Jurnal Politik Pemerintahan, 9(1).

Nugroho, Mulyanto et. al. (2016). Penerapan Standar Pelayanan Publik Pada Kelurahan di Wilayah Kota Kediri. Jurnal Hasil Penelitian LPPM Untag Surabaya, 1(02).

\section{c. Tesis/Disertasi}

Gusmasi (2008). Analisis Biaya Program Penanggulangan Gizi Buruk Berdasarkan SPM di Kabupaten Sambas Kalimantan Barat. Thesis tidak dipublikasikan.

Khozin, Muhammad (2010). Evaluasi Implementasi Kebijakan Standar Pelayanan Minimal bidang Kesehatan (Studi kasus Penerapan Standar Pelayanan Minimal Bidang Kesehatan pada Pemerintah Kabupaten Gunung Kidul). Thesis tidak dipublikasikan.

Kurniawan, Iwan (2011). Efektifitas Pengaturan Standar Pelayanan Minimal Dalam Perspektif Desentralisasi di Indonesia. Thesis tidak dipublikasikan.

Kurniawan, Iwan (2011). Efektifitas Pengaturan Standar Pelayanan Minimal dalam Perspektif Desentralisasi di Indonesia. Thesis tidak dipublikasikan.

Wijaya, Hendy (2010). Analisis Pembiayaan Kesehatan Daerah Program Kesehatan Ibu Dan Anak (KIA) Berdasarkan Standar Pelayanan Minimal (SPM) Pada Dinas Kesehatan Kabupaten Sambas. Thesis tidak dipublikasikan.

\section{d. Peraturan Perundang-Undangan}

Undang-Undang Nomor 25 Tahun 1999 tentang Pelayanan Publik.

Undang-Undang Nomor 32 Tahun 2004 tentang Pemerintahan Daerah jo UndangUndang Nomor 23 Tahun 2014 tentang Pemerintahan Daerah.

Peraturan Pemerintah Nomor 65 tahun 2005 tentang Pedoman Penyusunan dan Penerapan SPM.

Peraturan Menteri Kesehatan RI No. 741/Menkes/Per/VII/2008 tentang Standar Pelayanan Minimal Bidang Kesehatan di Kabupaten/Kota.

Peraturan Menteri Pekerjaan Umum Nomor: 14 /Prt/M/2010 tentang Standar Pelayanan Minimal Bidang Pekerjaan Umum dan Penataan Ruang.

Peraturan Menteri Pendidikan Nasional Republik Indonesia Nomor 15 Tahun 2010 tentang Standar Pelayanan Minimal Pendidikan Dasar di Kabupaten/Kota.

Peraturan Menteri Negara Perumahan Rakyat Nomor 16 Tahun 2010 tentang Petunjuk Teknis Perencanaan Pembiayaan Pencapaian Standar.

Pelayanan Minimal Bidang Perumahan Rakyat Daerah Provinsi 